\title{
EFFECTS OF RENT-SEEKING ON ECONOMIC GROWTH IN LOW-INCOME ECONOMIES
}

\author{
Zi Wen Vivien Wong", Fanyu Chen ${ }^{* * *}$ and Thian Hee Yiew*** \\ "Faculty of Business and Finance, Universiti Tunku Abdul Rahmana. Email: vivienwong@utar.edu.my \\ ${ }^{* *}$ Corresponding author. Faculty of Business and Finance, Universiti Tunku Abdul Rahmana. \\ Email: chenf@utar.edu.my \\ **** Faculty of Business and Finance, Universiti Tunku Abdul Rahmana. Email: yiewth@utar.edu.my
}

\begin{abstract}
Sluggish growth in low-income countries, despite the high performance in other economic indicators, motivates the literature to switch attention to institutions. Despite its crucial economic implications, there is limited attention on rent-seeking as a driver of economic growth in low-income countries. This paper investigates the effect of rent-seeking on growth in low-income countries from 2004 to 2017 using the system generalized method of moments estimator. The empirical results reveal that rent-seeking negatively affects growth, implying that it obstructs the pace of economic development in low-income countries. Hence, it is necessary for policymakers in these countries to adopt anti-rent-seeking policies to promote a rapid and sustainable growth.
\end{abstract}

Keywords: Rent-seeking; Economic growth; System generalized method of moments estimator; Low-income countries.

JEL Classifications: O43; H63; E02.

Article history:

Received : July 15, 2020

Revised : December 28, 2020

Accepted : January 17, 2021

Available Online: June 30, 2021

https://doi.org/10.21098/bemp.v24i2.1386 


\section{INTRODUCTION}

The world's socioeconomic condition has witnessed significant progress since the past two decades (World Bank, 2017). Credits have been given to globalization in the aspects of rapid technological diffusion and greater access to capital and global markets, which has in turn led to unprecedented rates of economic growth (Wang, 1990). As a result of globalization, resources, know-how, and technologies have been increasingly diffused at a rapid rate across nations, hence policy solutions to promote further progress proliferate. While these increasing trends have helped many nations and mankind to progress, other regions and populations seem to have been left behind due to violence, slow growth, and limited opportunity for improvement (Gwartney et al., 2006). This is because effective policies leading to positive and sustainable economic growth have not been adopted or are poorly implemented in these regions (World Bank, 2017). In other words, while the development policies around the globe have prioritized the policies and interventions needed for improving outcomes, little attention has been paid to analyze the reasons why these policies and interventions succeed in some nations or regions but fail in others.

While countries generally have a set of common development objectives, namely promoting economic growth and the sustainability of the development process, their policies do not always produce the same desired outcomes and contradictions do exist in reality. The common culprit associated with these contradictions seems to be institutional malfunction including pervasive rentseeking activities, which channel resources from the productive sectors to the unproductive sectors of these economies (Brooks et al., 1990). Accordingly, challenges faced especially by developing countries, which include weak delivery of services, violence, sluggish growth, natural resource curse, and the most prominent issue - rent-seeking - require reconsidering the process by which state and non-state agents interact to design and implement policies in such a way that uphold institutional quality for mitigating rent-seeking activities (Auriol, 2006). The objective of our study is to examine the effect of rent-seeking activities on economic growth in low-income economies.

Rent-seeking refers to the abuse of public office for private gain (World Bank, 1997). It involves expenditure by interest groups in the form of lobbying/bribery to obtain advantageous treatment from the government through public policy like regulation, taxation, and subsidies (Krueger, 1974). Particularly, the rent-seekers look for an opportunity to spend money in lobbying governments' decisions in order to gain extra 'rent' by bending these decisions in their favor. The existence of rent-seeking activities in an economy is a sign of poor institutional quality (Ugur and Dasgupta, 2011). This is because they create a distortion to the cost and incentive structure of an economy, trigger waste and misallocation of resources as public investment/funds might be channeled to unproductive sectors (See Barro, 1991), and destroy the development potential of the best entrepreneurs (Auriol et al., 2016). Hence, rent-seeking results in the reduction of economic efficiency through the misallocation of resources by governments, and ultimately impede economic growth and development.

In developing economies, where economic growth plays an especially important role in economic development, issues related to institutional quality 
seem to be a significant factor of the limited progress in economic development (Valeriani and Peluso, 2011). Based on the reports of the International Country Risk Guide and the Transparency International, we observed that the control of rent-seeking activities is weak, as indicated by low scores of Corruption Perception Index (CPI) for Low-Income Countries (LICs) when compared to the group of Middle-Income Countries (MICs) and High-Income Countries (HICs). We also observed that countries (such as Norway, Denmark, Finland, Netherland, New Zealand, and Singapore), which have been achieving high Gross Domestic Product (GDP) per capita are those that have better control of corruption, as indicated high scores of the CPI, and hence low level of rent-seeking activities. By contrast, nations (such as Tajikistan, Papua New Guinea, Madagascar, and Sierra Leone, Cambodia) characterized by low CPI scores(or high rent-seeking activities) are those with low GDP per capita and hence are LICs. See Table 1 for selected related literature. ${ }^{1}$

In these countries, quantitative control or quantitative easing has served as a by-product of the governments' attempts to affect the pace of development through centralised planning (Blomqvist and Mohammad, 1986). A centralized or authoritative planning process is exposed to limited competition and transparency, rent-seeking activities, a reduction in productivity and efficiency, and hence restricts economic growth (Blomqvist and Mohammad, 1986). Generally, the economic issues that exist in developing countries are often brought about by the side effects of such control by elites or self-interest groups. On the other hand, the public sector, alongside civilian and military bureaucracies tend to be organized naturally for collective action in the urban areas.

Motivated by institutional as well as growth-related issues faced by developing economies, this study employs the system Generalized Method of Moments (GMM) estimator to investigate the effect of rent-seeking activities on economic growth in LICs. We focus on LICs because these countries are experiencing an increasing trend of rent-seeking activities. It is observed that LICs have shown lack of effort to control rent-seeking activities. Based on the World Bank's World Governance Indicators report (i.e. World Governance Indicators, 2017), a majority of the LICs have experienced a decrease in the CPI score during the period 20102017, indicating that the efforts and the level of control of rent-seeking activities have been low in these countries. The report also revealed that the LICs' average CPI score is 26.59, which is far lower than the those of Middle-Income Countries (MICs) and High-Income Countries (HICs).

This study is crucial to the existing literature and the policy arena for a couple of reasons. First of all, it focuses on the institutional quality of the countries as the key driver of economic growth rather than the conventional drivers such as labor, human and physical capital accumulation, investment, among others (Juhro et al., 2020). Good quality institutions provides a country an incentive framework on transaction costs and the interaction among economic agents, which in turn influence the country's overall economic development (see North, 1991).

1 See https://www.transparency.org/en/cpi/2017/index/nzl 


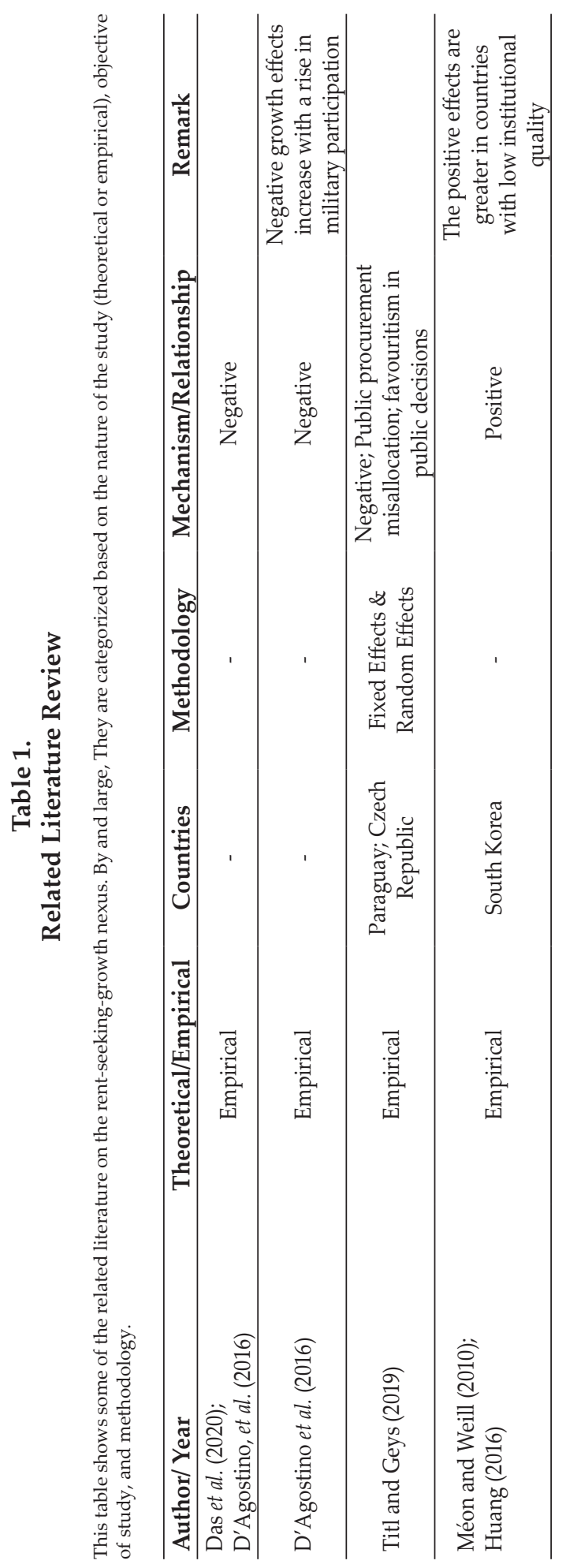


Second, this research is also relevant to the literature in the sense that its empirical results affirm the 'sand' or 'grease' on wheels hypothesis/puzzle and hence provide a clear and robust finding as compared to the mixed findings of prior studies in the literature. Our focus on LICs is unique to the literature because the existing studies on the rent-seeking-economic growth nexus mainly analyze the relationship in a wide scope of heterogenous countries (see Huang, 2016). The empirical findings and policy recommendations of these studies would suffer from the one-size-does-not-fit-for-all issue. Thus, the focus on the LICs by our is adequate because these countries desperately need high and sustainable growth to move upward to a higher economic ladder; they are also commonly deemed to have suffered from weak institutional quality in general (Blomqvist and Mohammad, 1986; Mishra et al., 2014).

Given the weak institutional and economic situations in LICs, we ask the following questions: What is the specific political determinant of economic growth in the LICs? What is the main obstacle impeding economic growth in these countries? While Comoros, Senegal and Zimbabwe were upgraded to lower middle-income status, there have been debates regarding why other countries retained their LICs status (Federal Reserve of St Louis, 2015) ${ }^{2}$. In order for LICs to move upward to a higher ladder, understanding the key determinants of economic growth is essential.

To enhance sustainable economic development in LICs and hence rid them of the poverty trap, enhancing the quality of institutions appears to be inevitable. However, to our knowledge, there have been limited research examining the effects of rent-seeking activities on economic growth in LICs. Instead, the literature mainly focuses on High-Income Countries (HICs) and on the MICs (see Auriol et al., 2016). This paper contributes to the literature in this regard by investigating the effect of rent-seeking behaviour on economic growth in LICs. The empirical finding of this study provides explanation to policymakers in the LICs as to why their countries have been persistently facing difficulties in stimulating and sustaining rapid economic growth despite the extensive efforts made by governments to attract more FDI, capital accumulation, etc. In other words, the finding provides policymakers in these countries a clear direction on the key aspect of the economy to be focused on especially when the conventional macroeconomic policies are ineffective to boost and to sustain growth and hence to move upward to a higher economic ladder.

The rest of the paper is organised as follows. Section II develops the theoretical framework. Section III explains the methodology. Section IV describes the data. Section $\mathrm{V}$ reports the empirical results and interprets the findings. Section VI concludes and provides the policy implication of the paper.

2 Majority of the low-income countries are earning 30 to 50 times lower (and sometimes even less than $\$ 1000$ per year in 2014) per capita income compared to high-income country like the United States. Based on the existing data, it takes around 170 to 200 years to converge to the United States living standards, by assuming that the growth rate of the United States remains constant at 2 percentage point per year. On the other hand, for middle-income countries to converge to high-income countries, they need to achieve growth rate of at least 11 percentage point per year continuously for 40 to 50 years. This implies that it is even more difficult for the low-income countries to catch up with the high-income countries in term of growth. Hence, the limited pace of income convergence and the relative income traps (faced by the low-income countries) appear to be real problems. 


\section{THEORETICAL FRAMEWORK}

To examine the effects of rent-seeking activities on economic growth, the basic theoretical framework of the study is based on the work of Barro (1991) and Mauro (1995) in which general production function is expressed as:

$$
Y_{i t}=T f\left(K_{i t}, L_{i t}\right)
$$

where $Y$ represents total output level; $T$ refers to total factor productivity; $K$ and $L$ refer to capital and labor, respectively. Where $t$ represent the time subscript and $i$ represent cross section. The total differentiation of $Y$ is given as:

$$
d Y_{i t}=f d T_{i t}+T\left(f_{k} d K_{i t}+f_{L} d L_{i t}\right)
$$

Dividing Equation (2) by $Y$ yields a decomposition similar to Solow (1956)

$$
\frac{d Y_{i t}}{Y_{i t}}=\frac{d T_{i t}}{T_{i t}}+T f_{K} \frac{d K_{i t}}{Y_{i t}}+\frac{f_{L} L}{f} \frac{d L_{i t}}{L_{i t}}
$$

Equation (3) can be explained by using Schumpeterian growth theory of economic development ${ }^{4}$, whereby it distinguished two components the progress of an economy. The first relates to the growth component associated with the growth rate in capital and labor under the changes in factor availability. The second relates to the development component associated with the forces driving total productivity growth in the production function under social and technological changes (Schumpeter, 1961). The said components are characterized as the following:

$$
G R_{i t}=F\left[\gamma_{i t}, I Y_{i t}, d L L_{i t}\right]
$$

where $G R_{t}$ represents the growth rate of real GDP; $\gamma_{i t}$ refers to the total factor of productivity; $I Y_{i t}$ denotes the investment-output ratio; and $d L L_{i t}$ represents the growth rate of labor. The marginal productivity of capital is shown by $F_{I Y ;}$; the output elasticity of labor is $F_{d L L}$; and $F_{\gamma}$ is assumed to be equal to 1 , where $t$ represent the time subscript and $i$ represent cross section.

To examine economic growth based on the general productivity function of Barro (1991), few variables will be included into the model: factors of production like capital formation, labor force, population, and others. Essentially, to capture rent-seeking activities, CPI is used as the proxy for these activities. Thus, our growth model can be illustrated by the following function:

3 This equation is used to examine the difference in growth performance across countries and differs from the traditional growth studies.

4 The Schumpeterian growth theory attempts to explain the gap between growth and economic development across countries. Besides, it analyses institutional development in a simple framework to capture the concept of growth-enhancing policies or how institutions may change based on the country's level of technology development 


$$
G R=F[\gamma, I Y, d L L, \text { Rent }- \text { seeking, Labor Force, Capital,Population }]
$$

in which the growth components include labor force, capital, and population, other than rent-seeking. To ensure the effectiveness and efficiency of the estimated coefficient capturing the effects of rent-seeking activities on growth, it is crucial to control other growth determinants.

The rent-seeking activities tend to decrease economic growth through the misallocation of resources, and reduction in the efficiency and transparency of public administration(see Auriol et al., 2016). Therefore, poor institutional quality creates an opportunity for rent-seekers to find their own special interest and redirects resources - wealth is redistributed by violating regulations. However, in the context of LICs especially, rent-seeking activities are heterogeneous (Iqbal and Daly, 2014) as institutional quality differs by countries. For example, the rule of law is not equally effective, property rights are not equally well defined and democratic rights are not equally extensive, and these elements differ across LICs. Following that, there is still a debate on whether rent-seeking activities are 'sand or oil to machine' and hence the existing literature regarding the hypothesis is still inconclusive.

\section{METHODOLOGY}

\section{A. Dynamic Panel GMM Estimation}

To include lagged dependent variables in our empirical models indicates that there is a correlation between independent variables and the error term since the lagged dependent variables (i.e. first lags of economic growth, lagged dependent income inequality, and public expenditure) depend on $u_{i t-1}$, which is a function of the $\mu_{i t-1}$ (i.e. lag of country specific effect). Due to this correlation, Eq. (6) will suffer from the dynamic panel bias. In other words, under the fixed effects estimator, the country-specific effect error term would be wiped out within the transformation. However, $\underline{\varepsilon}_{l}=\frac{1}{T} \sum_{t=1}^{T} \varepsilon_{i t}$, the correction between the transformed error term and the transformed lagged dependent variable is a function of $1 / T$, indicating that when $T$ is large the correlation would only be negligible. Otherwise, the standard fixed effects estimator would be biased downwards. Therefore, by employing the system GMM estimator introduced by Arellano-Bond (1991), we basically differences the model to remove any time-invariant country-specific effects. The system GMM estimator treats all regressors are stationary by differencing them, and thus it eliminates the problem of endogeneity caused by the correlation of the country-specific effect and the independent variables. This study examined 19 LICs $(N)$ and period cover from 2004 to $2017(T)$, fulfilling the requirement that $N>T$ for correct application of the system GMM estimator. There should be no concern regarding the small number of time series observations, because the size of the cross-sectional dimension of the panel determines the asymptotic properties of the system GMM estimator. The one-step and two-step system GMM are asymptotically normal under this setting. The difference between one-step and two-step system GMM is that the two-step system GMM estimator provides small variance asymptotically as compared to the one-step system GMM estimator. 
Besides, using an optimal weighting matrix, the two-step system GMM estimator outperforms the one-step system GMM estimator because the former generates lower bias and standard errors compared with the former. Overall, the system GMM estimator has flexibility and allows lags of the endogenous variables to be efficiently incorporated in the model. Thus, this allows for many instrumental variables to be used in the estimations. To avoid potential proliferation of instruments, we truncate and collapse lags to reduce the instrument count in the system GMM estimation.

\section{B. Empirical Approach}

Our dynamic empirical economic growth model, which includes a lagged dependent variable, is as follows:

$$
\begin{aligned}
\ln R G D P G_{i t}= & \alpha_{i}+\gamma \ln R G D P G_{i t-1}+\beta_{1} \ln R S_{i t}+\beta_{2} \ln L B F_{i t}+\beta_{3} \ln C P_{i t}+ \\
& \beta_{4} \ln P O P_{i t}+u_{i t}
\end{aligned}
$$

where subscripts $i$ and $t$ refer to country and year, respectively; RGDPG is the real GDP per capita growth; $R S$ is rent-seeking; $L B F$ is total labor force; $C P$ is gross capital formation; and $P O P$ is the total population. $u$ is the error term that contains country- and time-specific fixed effects, $u_{i t}=\mu_{i}+\varepsilon_{t}+v_{i t}$, where $v_{i t}$ is assumed to be independent and identically distributed with zero mean and constant variance. The prefix " $l n$ " represents the natural logarithm; $\alpha_{i}$ is the country-specific constant term; and $\gamma, \beta_{1}, \beta_{2}, \beta_{3}$ and $\beta_{4}$ are the slopes of the respective estimated parameters. In addition, the lagged dependent variable is incorporated into the model in order to account for temporal dependence on the previous real GDP per capita growth of the current, which can justify the gradual changes in economic growth.

Theoretically $\beta_{1}$ is expected to carry a negative sign to indicate that higher rentseeking activities tend to impede economic growth. Rent-seeking is a sign of deep institutional weakness, and causes a lower rate of investment and expenditure (in education and health), widening income inequality, decreasing foreign investors' confidence, and increasing social cost, thereby retarding economic growth.

Based on the mainstream rent-seeking theory literature, rent-seeking has adverse effects on the public welfare (Gyimah-Brempong, 2002). On the one hand, this is because part of the resource rent-seeking agents is not directed to goods and output growth. On the other hand, it is distracted by the institutional conditions created for reallocation of already created value in the interest of the respective lobbying agents. This, in turn, indicates a societal loss in two forms, namely the loss of production volume due to wastage of resources to obtain rents, and the loss due to inefficient handling/issuing of property rights. These costs often outweigh the amount of possible rent obtained. What is more interesting is that there might be competition among economic agents for a monopoly position in the industry. In the process of competition, losers expend resources rather than invest in the production of goods. The expended resources or funds are, in turn, redistributed to the competition's winners, and ultimately providing no welfare or benefit to the society as a whole(Tullock, 1967). 
The redistribution activity that deplete resources, i.e. rent-seeking activity, is so costly to growth for two reasons. Firstly, rent-seeking activities exhibit very natural increasing returns. In other words, an ascent of rent-seeking activities leads these activities to be more attractive, compared to productive activities, and ultimately results in multiple equilibria in the economy, with "bad" equilibrium exhibiting substantially high levels of rent-seeking, but low level of output. Particularly, there are three mechanisms through which the increasing returns in rent-seeking influence economic growth. One of them is the fixed set-up cost of rent-seeking system like a legal code. Once set up, lawyers can sue each other's clients cheaply and easily, which they could not do so otherwise. Besides, rent-seeking would be self-fulfilling because offence paves ways for a demand for defence. For example, if a customer hires lawyer, his supplier will do likewise, thereby leading to a form of increasing returns. The last mechanism is the "strength in numbers" possessed by the rent-seekers. If only a few people were involved in burglary, they would tend to be caught. However, if many of them steal, the chance of being caught is much lower, and, therefore, the returns to looting are higher. All these mechanisms that depend on increasing returns to the aggregate rent-seeking technology could reach multiple equilibria, some of which have an extremely high level of rentseeking and a low level of income.

Secondly, rent-seeking activities, especially by public officers, tend to impede innovation more than the private rent-seeker. Since innovation serves as one of the key engines of growth, public rent-seeking, as compared to production, retards growth in a more extreme manner. In particular, innovators need governmentsupplied goods like import quotas, licenses, permits, and others alike much more than incumbent producers. Based on the discussed theoretical foundation, the rent-seeking activities hypothesis - high rent-seeking activities reduce economic growth - is developed and therefore, $\beta_{1}$ is expected to be negative.

Other than the main explanatory variable (rent-seeking), it is also important to theoretically analyze the linkage between the control variables, namely labor/ human capital, physical capital, and population, and economic growth. While $\gamma$, $\beta_{2}$, and $\beta_{3}$ are expected to be positive, $\beta_{4}$ is expected to carry a negative sign. We also estimate Eq. (6) using the systemin GMM estimator. To ensure the consistency of the system GMM estimates, we performed two types of specification test, namely Sargan's over-identifying restriction test and the serial correlation test of the disturbance (Arellano and Bond, 1991). Failure to reject the null hypothesis of the Sargan test would imply that the instruments are valid and hence the model is correctly specified. In the serial correlation test, on the other hand, a rejection of the null hypothesis under the $A R(1)$ and $A R(2)$ tests imply absence of first and second order serial correlation.

\section{DATA}

We use CPI as the proxy for rent-seeking. According to Iqbal and Daly (2014), rentseeking is considered as any activity in which public power is exercised for private gain including the misuse of public resources. The rent-seeking dataset is obtained from World Governance Indicators (WGI) and Transparency International (TI). The sample period of the dataset spans from 2004 to 2017. 
The descriptive statistics of the variables (in logarithms) are summarized in Table 2. Economic growth, which is the dependent variable, is proxied by real GDP per capita growth and is measured in constant 2010 USD (obtained from World Development Indicators (WDI) database compiled by the World Bank). The highest value of economic growth per capita is $4.435 \%$, while the lowest value is $-0.261 \%$. Other than that, the variability of economic growth per capita is $0.285 \%$, while the average value is $3.236 \%$. Rent-seeking activities, proxied by the CPI indices (obtained from WGI and TI), are scaled from 1 to 6 and from 1 to 100 , respectively; higher value implies better control of corruption. For the sake of consistency, the data for the two rent-seeking activities proxies (namely the WGI and TI) has been standardized from 1 to 10 . The highest value for rent-seeking activities (measured by WGI) is 4.324 , while the lowest value is 0.352 ; similarly, the average value is 3.001 and the variability is 0.839 . For rent-seeking proxied by the $\mathrm{TI}$, the highest value is 4.007 , while the lowest value is 2.640 ; similarly, the average value of the data is equal to 3.270 , while the variability is 0.235 . Notably, the data is rebased in order to show that higher values indicate higher levels of rent-seeking activities in the LICs.

Table 2.

Descriptive Statistics and Source of Data

This table presents descriptive statistics, namely the mean, Standard Deviation (SD), maximum (Max) and minimum (Min) for the period 2004-2017. The variables, namely real GDP per capita growth, rent-seeking activities, total labor force, capital, and total population, are in the first column. The countries include Benin, Burundi, Cambodia, Chad, Ethiopia, Papua New Guinea, Haiti, Liberia, Madagascar, Malawi, Mali, Mozambique, Nepal, Rwanda, Sierra Leone, Tanzania, Uganda, The Gambia, Zimbabwe. All variables are in natural logarithm.

\begin{tabular}{|c|c|c|c|c|c|c|}
\hline Variable & Source & $\begin{array}{c}\text { Unit of } \\
\text { measurement }\end{array}$ & Mean & SD & Min & Max \\
\hline $\ln R G D P G$ & WDI & $\begin{array}{l}\text { Constant } \\
\text { 2010US\$ } \\
\end{array}$ & 3.236 & 0.285 & -0.261 & 4.435 \\
\hline $\ln R S$ & $\begin{array}{c}\text { WGI } \\
\text { TI }\end{array}$ & $\begin{array}{c}\text { Index (1-6) } \\
\text { Index (1-100) }\end{array}$ & $\begin{array}{l}3.001 \\
3.270 \\
\end{array}$ & $\begin{array}{l}0.839 \\
0.235 \\
\end{array}$ & $\begin{array}{l}0.352 \\
2.640 \\
\end{array}$ & $\begin{array}{l}4.324 \\
4.007 \\
\end{array}$ \\
\hline $\ln L B F$ & $\begin{array}{c}\text { International } \\
\text { Financial } \\
\text { Statistics } \\
\end{array}$ & Total labor force & 0.027 & 0.011 & -0.026 & 0.042 \\
\hline $\ln C P$ & $\begin{array}{c}\text { United } \\
\text { Nation } \\
\text { Statistics } \\
\text { Division } \\
\end{array}$ & $\begin{array}{l}\text { Gross capital } \\
\text { formation }(\% \text { of } \\
\text { GDP) }\end{array}$ & 0.131 & 0.272 & -1.115 & 1.503 \\
\hline $\ln P O P$ & WDI & Total population & 16.421 & 0.873 & 14.151 & 18.469 \\
\hline
\end{tabular}

In addition, the labor force is proxied by total labor force, which is measured in thousands (obtained from the International Financial Statistics). Its highest value is 0.042 , while its lowest value is -0.026 ; the average value for this variable is 0.027 , while the variability is equal to 0.011 . Capital formation is represented by capital investment/capital accumulation, measured in percentage of GDP (obtained from the United Nation's Statistic Division). Its highest value is 1.503\%, while its lowest value is $-1.115 \%$; the variability is $0.272 \%$, while the average value is $0.131 \%$. Lastly, population is proxied by total population, measured in thousands (obtained from 
WDI, World Bank). Its highest value is 18.469 , while its lowest value is equal to 14.151, with a variability of 0.873 and an average of 16.421 .

\section{EMPIRICAL RESULTS}

Table 3 presents the empirical results of the dynamic panel Equation (6) using the system GMM estimator. In particular, the rent-seeking indicator being employed in the estimations in Models $1 \mathrm{a}, 1 \mathrm{~b}$, and $1 \mathrm{c}$ is the CPI obtained from WGI, whereas Models 2a, 2b, and 2c depict the robustness checks for the above-mentioned models-capturing rent-seeking by using corruption perception index obtained from TI. In addition, Models 1a, 1b, and 1c use the one-step system GMM, twostep system GMM, and two-step system GMM with robust standard errors, respectively. Models $2 \mathrm{a}, 2 \mathrm{~b}$, and $2 \mathrm{c}$ are the robustness checks equivalent of Models $1 \mathrm{a}, 1 \mathrm{~b}$, and $1 \mathrm{c}$ and thus use the same system GMM estimators.

The lagged dependent variable is statistically significant, which implies that the dynamic system GMM estimator is an appropriate estimator and that the empirical results can be relied upon for statistical inference. The results indicate that rent-seeking activities negatively affect economic growth in the LICs, when rent-seeking is measured by both CPI indices (i.e. WGI and TI). The negative sign of the corruption index's coefficient in Model 1c (WGI) suggests the existence of an inverse relationship between rent-seeking and economic growth - rent-seeking plays a role in decreasing economic growth over time. Specifically, a percentage rise in rent-seeking activities is associated with a 0.15 per cent fall in economic growth.

This result is in line with the findings of Paul (2010). It is also consistent with the missiles seek heat hypothesis (Aidt, 2016), the invertibility hypothesis (Aidt, 2016), and Galtung's (1971) structural theory of imperialism. Based on Aidt's (2016) missiles seek heat hypothesis of rent-seeking, the occurrence of contestable rents produces socially costly activities to target at winning the rents. Rent-seeking activities also involve social cost (a social problem in the economy) as they will lead to policy distortions due to the inequitable and unfair allocation of public resources and funds. Other rent-seeking theory also hypothesize that rent-seeking activities tend to decrease investment. In short, our main finding that rent-seeking activities impede economic growth in LICs is in line with various studies. World Bank defines rent-seeking activity as one of the most demonised' variables that tend to retard economic growth and social development by increasing cost of business and creating indecisions by decreasing competency of infrastructure and public investment and by lowering productivity of a country.

Furthermore, the positive coefficient of capital accumulation (as shown in Model 1c) indicates its positive relationship with economic growth. This suggests that, in order to promote economic growth for LICs, capital accumulation should be a key focus of policymakers. In particular, a percentage increase in capital accumulation is associated with a 0.412 per cent increase in economic growth. This result further supports the idea of Solow's (1956) growth model, which indicates that capital accumulation is a significant contributor to the level of production. Capital accumulation is also a main source of growth in endogenous growth theory to accelerate the economic development. The result is also consistent with the findings of Bal et al. (2016). 
The estimated models are well specified as they pass all the three diagnostics checks. Specifically, the Sargan and Hansen test does not reject the overidentification restriction null hypothesis. Similarly, the $A R(1)$ test result shows a rejection of the null hypothesis of the absence of first-order serial correlation, but the $A R(2)$ test result shows no rejection of the null hypothesis of second-order serial correlation.

The results obtained using the alternative measure of corruption perception (or rent-seeking) from TI are shown in Models 2a, 2b, and 2c. These results allow us to examine the validity or robustness of our main results. Based on Model 2c, a percentage increase in rent-seeking activities will reduce economic growth by 0.184 per cent. The result shows consistency with the baseline result in both coefficient's sign and magnitude, reinforcing that rent-seeking activities hamper economic growth in LICs.

Table 3.

\section{System GMM Results with Robustness Checks}

This table shows the estimates obtained using the system GMM estimator to estimate our dynamic panel regressions. Values in parentheses are $t$-statistics, except for Sargan and Hansen test for serial correlation, which are $p$-values. ${ }^{*}, * *$, and ${ }^{* * *}$ indicate $10 \%, 5 \%$, and $1 \%$ significant levels, respectively.

\begin{tabular}{|c|c|c|c|c|c|c|}
\hline & Model & Model & Model & Model & Model & Model \\
\hline Variable & $\begin{array}{c}\text { 1a } \\
\text { one-step } \\
\text { system } \\
\text { GMM }\end{array}$ & $\begin{array}{c}1 b \\
\text { two-step } \\
\text { system } \\
\text { GMM }\end{array}$ & $\begin{array}{c}\text { 1c } \\
\text { two-step } \\
\text { system } \\
\text { GMM with } \\
\text { robust } \\
\text { standard } \\
\text { errors (SE) }\end{array}$ & $\begin{array}{c}2 \mathrm{a} \\
\text { one-step } \\
\text { system } \\
\text { GMM }\end{array}$ & $\begin{array}{c}2 b \\
\text { two-step } \\
\text { system } \\
\text { GMM }\end{array}$ & $\begin{array}{c}2 \mathrm{c} \\
\text { two-step } \\
\text { system } \\
\text { GMM with } \\
\text { robust } \\
\text { standard } \\
\text { errors (SE) }\end{array}$ \\
\hline $\ln R G D P G_{i t-1}$ & $\begin{array}{l}0.206 \\
(2.90)\end{array}$ & $\begin{array}{l}0.314^{* *+1} \\
(5.28)\end{array}$ & $\begin{array}{c}0.314^{* * *} \\
(2.71)\end{array}$ & $\begin{array}{l}0.179^{* *} \\
(2.07)\end{array}$ & $\begin{array}{l}0.332^{* *+*} \\
(4.49)\end{array}$ & $\begin{array}{l}0.332^{*} \\
(1.91)\end{array}$ \\
\hline $\ln R S(W G I)$ & $\begin{array}{c}-0.00645 \\
(-0.24)\end{array}$ & $\begin{array}{l}-0.150^{* * * *} \\
(-2.59)\end{array}$ & $\begin{array}{l}-0.150^{* * *} \\
(-1.99)\end{array}$ & - & - & - \\
\hline $\ln R S(T I)$ & - & - & - & $\begin{array}{r}-0.0717 \\
(-0.63)\end{array}$ & $\begin{array}{c}-0.184^{* *} \\
(-2.21)\end{array}$ & $\begin{array}{c}-0.184^{* *} \\
(-2.08)\end{array}$ \\
\hline $\ln L B F$ & $\begin{array}{c}0.0192 \\
(0.88)\end{array}$ & $\begin{array}{l}0.131 \\
(1.53)\end{array}$ & $\begin{array}{l}0.131 \\
(1.34)\end{array}$ & $\begin{array}{c}0.0211 \\
(0.88)\end{array}$ & $\begin{array}{c}-0.0423 \\
(-0.58)\end{array}$ & $\begin{array}{l}-0.0423 \\
(-0.35)\end{array}$ \\
\hline $\ln C P$ & $\begin{array}{c}0.534^{*+*+4} \\
(3.93)\end{array}$ & $\begin{array}{c}0.412^{* * * *} \\
(3.99)\end{array}$ & $\begin{array}{l}0.412^{*} \\
(1.80)\end{array}$ & $\begin{array}{l}0.445^{*} \\
(2.38)\end{array}$ & $\begin{array}{c}0.446^{* * *+} \\
(3.79)\end{array}$ & $\begin{array}{l}0.446^{*} \\
(1.81)\end{array}$ \\
\hline $\ln P O P$ & $\begin{array}{l}1.634 \\
(0.52)\end{array}$ & $\begin{array}{l}3.900 \\
(0.53)\end{array}$ & $\begin{array}{l}3.900 \\
(0.41)\end{array}$ & $\begin{array}{l}1.269 \\
(0.37)\end{array}$ & $\begin{array}{l}-4.851 \\
(-0.98)\end{array}$ & $\begin{array}{l}-4.851 \\
(-0.56)\end{array}$ \\
\hline Cons & $\begin{array}{c}2.160^{* *+*} \\
(5.38)\end{array}$ & $\begin{array}{r}-0.155 \\
(-0.09)\end{array}$ & $\begin{array}{r}-0.155 \\
(-0.07)\end{array}$ & $\begin{array}{c}2.029^{* * * *} \\
(3.91)\end{array}$ & $\begin{array}{l}2.336 \\
(1.85)\end{array}$ & $\begin{array}{l}2.336 \\
(1.00)\end{array}$ \\
\hline $\begin{array}{l}\text { Number of } \\
\text { Obs }\end{array}$ & 247 & 247 & 247 & 220 & 220 & 220 \\
\hline $\begin{array}{l}\text { Number of } \\
\text { groups }\end{array}$ & 19 & 19 & 19 & 19 & 19 & 19 \\
\hline $\begin{array}{l}\text { Number of } \\
\text { instruments }\end{array}$ & 86 & 86 & 86 & 50 & 50 & 50 \\
\hline
\end{tabular}


Table 3.

System GMM Results with Robustness Checks (Continued)

\begin{tabular}{lcccccc}
\hline & Model & Model & Model & Model & Model & Model \\
\hline Variable & $\begin{array}{c}\text { 1a } \\
\text { one-step } \\
\text { system } \\
\text { GMM }\end{array}$ & $\begin{array}{c}\text { 1b } \\
\text { two-step } \\
\text { system } \\
\text { GMM }\end{array}$ & $\begin{array}{c}\text { 1c } \\
\text { two-step } \\
\text { system } \\
\text { GMM with } \\
\text { robust } \\
\text { standard } \\
\text { errors (SE) }\end{array}$ & $\begin{array}{c}\text { 2a } \\
\text { one-step } \\
\text { system } \\
\text { GMM }\end{array}$ & $\begin{array}{c}\text { 2b } \\
\text { two-step } \\
\text { system } \\
\text { GMM }\end{array}$ & $\begin{array}{c}\text { 20-step } \\
\text { twMstem } \\
\text { GM with } \\
\text { robust } \\
\text { standard } \\
\text { errors (SE) }\end{array}$ \\
\hline AR1 & $-5.978^{* * *}$ & $-1.719^{*}$ & $-1.674^{*}$ & $-4.523^{* * *}$ & $-1.907^{*}$ & $-1.777^{*}$ \\
AR2 & -1.150 & -0.419 & -0.369 & -0.818 & -0.277 & -0.237 \\
Sargan & 84.68 & 84.68 & 84.68 & 39.31 & 39.31 & 39.31 \\
Hansen & & 11.30 & 11.30 & & 10.28 & 10.28 \\
\hline
\end{tabular}

We also performed the cross-sectional dependence test developed by Pesaran (2004) to check cross-sectional dependency issues in the models for the two different proxies of corruption perception index. Table 4 reports the results and it shows that the cross-sectional dependence test failed to reject the null hypothesis of cross-sectional independence and, therefore, we conclude that cross-sectional dependency issues do not drive our results.

Table 4.

Cross-sectional Dependence Test

The table shows the cross-sectional dependence test results. Values in parentheses represent $p$-values.

\begin{tabular}{lcc}
\hline & Model 1c & Model 2c \\
\hline $\begin{array}{l}\text { Pesaran's test of cross-sectional } \\
\text { independence }\end{array}$ & $1.042(0.298)$ & $-0.051(0.959)$ \\
\hline
\end{tabular}

\section{CONCLUSION AND POLICY IMPLICATION}

The problem of rent-seeking is widespread and has caught the attention of various policymakers and researchers. A widely raised question is whether rent-seeking negatively influences growth. This study uses the system GMM estimator to estimate dynamic panel regressions of economic growth on rent-seeking in lowincome countries over the period 2004-2017.

We find that rent-seeking has a negative and significant impact on economic growth in low-income countries. This finding supports the conventional view that rent-seeking is an impediment to economic growth, implying that efforts to maintain and uphold institutional quality, especially in low-income countries are crucial in promoting the status of low-income countries to middle-income countries. As such, low-income countries are advised to effectively and efficiently curb rent-seeking activities by actively adopting anti-rent seeking policies like anticorruption and anti-bribery policies to tackle individuals, who tend to participate in rent-seeking activities, such as giving or receiving bribery payment from third 
parties. Besides, enforcing rules and regulation is crucial in promoting strong institutional quality by strengthening or streamlining bureaucracy/process of red tape, thus reducing rent-seeking opportunities for rent-seekers to engage in this process and obtain special interests/benefits. Through the right transformation of the institutional framework of low-income countries, rapid and sustainable economic growth can be achieved.

Nevertheless, recognition of the ill-effects of rent-seeking may not be sufficient to reverse them. For instance, a decrease in corruption level is only growthpromoting if supported by well-structured institutions. This paradigm of selfinterest motivated revolutionary activities and, thus, the ambiguity, opens up the room for further innovative and more constructive research on it. Besides, future researchers are recommended to employ the bias corrected least square dummy variable estimator, which can cater for small sample sizes and small time periods when investigating the impact of rent-seeking on economic growth.

\section{REFERENCES}

Aidt, T. S. (2016). Rent Seeking and the Economics of Corruption. Constitutional Political Economy, 27, 142-157.

Arellano, M., \& Bond, S. (1991). Some Tests of Specification for Panel Data: Monte Carlo Evidence and an Application to Employment Equation. Review of Economic Studies, 58, 277-297.

Auriol, E. (2006). Corruption in Procurement and Public Purchase. International Journal of Industrial Organization, 24, 867-885.

Auriol, E., Straub, S., \& Flochel, T. (2016). Public Procurement and Rent-seeking: The Case of Paraguay. World Development, 77, 395-407.

Bal, D. P., Dash, D. P., \& Subhasish, B. (2016). The Effects of Capital Formation on Economic Growth in India: Evidence From ARDL-bound Testing Approach. Global Business Review, 17, 1388-1400.

Barro, R. J. (1991). Economic Growth in a Cross Section of Countries. The Quarterly Journal of Economics,106, 407-443.

Blomqvist, Å., \& Mohammad, S. (1986). Controls, Corruption, and Competitive Rent-Seeking in LDCs. Journal of Development Economics, 21, 161-180.

Brooks, M. A., Heijdra, B. J., \& Lowenberg, A. D. (1990). Productive Versus Unproductive Labor and Rent Seeking: Lessons from History. Journal of Institutional and Theoretical Economics (JITE), 419-438.

D’Agostino, G., Dunne, J. P., \& Pieroni, L. (2016). Spending, Corruption and Economic Growth. World Development, 84, 190-205.

Das, A., Dash, D. P., \& Sethi, N. (2020). Innovation, Corruption, and Economic Growth in Emerging Asia. Buletin Ekonomi Moneter dan Perbankan, 23, 347-364.

Federal Reserve Bank of St Louis. (2015). Trapped: Few Developing Countries Can Climb the Economic Ladder or Stay There. https://www.stlouisfed.org/ publications/regional-economist/october-2015/trapped-few-developingcountries-can-climb-the-economic-ladder-or-stay-there

Galtung, J. (1971). A Structural Theory of Imperialism. Journal of Peace Research, 8, 81-117.

Gwartney, J. D., Holcombe, R. G., \& Lawson, R. A. (2006). Institutions and the Impact of Investment on Growth. Kyklos, 59, 255-273. 
Gyimah-Brempong, K. (2002). Corruption, Economic Growth, and Income Inequality in Africa. Economics of Governance, 3, 183-209.

Huang, C. J. (2016). Is Corruption Bad for Economic Growth? Evidence from AsiaPacific Countries. The North American Journal of Economics and Finance, 35, 247256.

Iqbal, N., \& Daly, V. (2014). Rent Seeking Opportunities and Economic Growth in Transitional Economies. Economic Modelling, 37, 16-22.

Juhro, S. M., Narayan, P. K., Iyke, B. N., \& Trisnanto, B. (2020). Is There a Role for Islamic Finance and R\&D in Endogenous Growth Models in the Case of Indonesia? Pacific-Basin Finance Journal, 62, 101297. https://doi.org/10.1016/j.pacfin.2020.101297

Krueger,A.O. (1974). The Political Economy of Rent Seeking Society. American Economic Review, 64, 291-303.

Mauro, P. (1995). Corruption and Growth. The Quarterly Journal of Economics, 110, 681-712.

Méon, P. G., \& Weill, L. (2010). Is Corruption an Efficient Grease?. World development, 38, 244-259.

Mishra, P., Montiel, P., Pedroni, P., \& Spilimbergo, A. (2014). Monetary Policy and Bank Lending Rates in Low-income Countries: Heterogeneous Panel Estimates. Journal of Development Economics, 111, 117-131.

North, D. C. (1991). Institutions. Journal of Economic Perspectives, 5, 97-112.

Paul, P. B. (2010). Does Corruption Foster Growth in Bangladesh? International Journal of Development Issues, 9, 246-262.

Pesaran, M. H. (2004). General Diagnostic Tests for Cross Section Dependence in Panels (No. 1229). CESifo Working Paper.

Schumpeter, J. A. (1961). The Theory of Economic Development: An Inquiry Into Profits, Capital, Credit, Interest, and the Business Cycle. Transl. by Redvers Opie: Oxford University Press.

Solow, R. M. (1956). Technical Change and the Aggregate Production Function. The Review of Economics and Statistics, 312-320.

Titl, V., \& Geys, B. (2019). Political Donations and the Allocation of Public Procurement Contracts. European Economic Review, 111, 443-458.

Tullock, G. (1967). The Welfare Costs of Tariffs, Monopolies, and Theft. Economic Inquiry, 5, 224-232.

Ugur, M., \& Dasgupta, N. (2011). Corruption and Economic Growth: A MetaAnalysis of the Evidence on Low-income Countries and Beyond. MRPR Paper, $1-43$.

Valeriani, E., \& Peluso, S. (2011). The Impact of Institutional Quality on Economic Growth and Development: An Empirical Study. Journal of Knowledge Management, Economics and Information Technology, 1, 1-25.

Wang, J. Y. (1990). Growth, Technology Transfer, and the Long-run Theory of International Capital Movements. Journal of International Economics, 29, 255271.

World Bank. (1997). World Development Report 1997: The State in a Changing World. New York: Oxford University Press.

World Bank. (2017). World Bank Annual Report 2017. Retrieved from https:// thedocs.worldbank.org/en/doc/9084815074037546700330212017/original/ AnnualReport2017WBG.pdf 
This page is intentionally left blank 